\title{
The Research Progress of Detection Method of Formaldehyde in Food
}

\author{
Xuan Zhang, Xiaosheng Shen, Yuan Wang, Youqiong Cai, Dongmei Huang* \\ East China Sea Fishery Research Institute, Chinese Academy of Fishery Sciences, Shanghai \\ 200090, China
}

Email: zhangxuan0430@163.com

\begin{abstract}
Keywords: Formaldehyde, Detection Method, Research Progress, Food
Abstract. Formaldehyde (FA) in food is a hot research topic, it widely exists in many organisms, such as marine products, meat and plant material. As a serious threat to human health, FA of manmade addition in food was forbidden in China. This paper summarized the advance in detection FA in food, and the work in the future was prospected.
\end{abstract}

\section{Introduction}

Recently, people are paying more attention to FA in food. FA as a mutagenic and carcinogenic volatile toxic aldehyde [1], even less dose of it can cause pain, vomiting, lethargy and coma, large amounts can lead to death [2]. As a toxic substance, FA is easy to react with nucleophilic material, causing DNA damage [3]. Studies have shown that parts of the Alzheimer's disease are also associated with the intake of FA [4]. As a serious threat to human health, FA ranked second on the priority control list of toxic chemicals in China [5]. In 2004, FA was categorized in Group I as 'carcinogenic to humans' by the International Agency for Research on Cancer (IARC) [6]. The United States Environmental Protection Agency recommended daily intake of FA as no more than $0.2 \mathrm{mg} / \mathrm{kg}$ of the body weight. In 1985, Italian health departments set limit of FA in cod and shellfish aquatic products respectively $60 \mathrm{mg} / \mathrm{kg}$ and $10 \mathrm{mg} / \mathrm{kg}$ [7], while Chinese ministry of agriculture, set it to 10 $\mathrm{mg} / \mathrm{kg}$ in aquatic products since 2002 [8].

There are two ways resulting in high levels of FA, one is the artificial added, the other one is that food produces FA during storage or processing. Commonly FA aqueous solution on the market sales as formalin. In food industry, FA can be used as pesticide, fungicide, preservative and decolorizer. FA of manmade addition in food was forbidden in China. However, high content of FA on the market was always detected.

\section{The Concentration and States of FA in Food}

FA widely exists in many organisms, such as marine products, meat and plant material. Table 1. shows the study of FA content in various organisms. FA content was variable, content of FA in Bumbalo is very high round of $63.8 \sim 163 \mathrm{mg} / \mathrm{kg}$, it also shows high FA levels in vegetables and fruits round of $3.6 \sim 35.0 \mathrm{mg} / \mathrm{kg}$, in addition, FA in mushroom reaches up to $380 \mathrm{mg} / \mathrm{kg}$. Duan et al. successively determined the background value of FA in 699 fresh aquatic samples of 37 species which included 19 kinds of marine fishes, 9 kinds of crustaceans, 5 kinds of shellfish and 4 kinds of cephalopods. The FA content of marine fishes was the highest, the cephalopods was higher, the crustaceans and shellfish was the lowest [12]. Both domestic and foreign scholars have suggested that organisms could produce FA itself, as a kind of animal metabolites in the body, it had vital significance for some amino acid biosynthesis. According to the existing research results, it is generally believed that FA in food is produced by enzymatic pathway and thermal processing [13]. Besides the enzymatic pathway, FA is steadily accumulated during the thermal processing $[14,15]$.

FA could react with protein, amino acid and creatinine [16, 17], which makes free and bound forms of FA in organisms. "Total" formaldehyde is the sum of these two forms. Bound FA could be extracted through steam distillation under the sulfuric acid or phosphoric acid solution $(1 \%-40 \%)$. Therefore, it is essential to specify whether free or bound formaldehyde is being determined when reporting FA content in tissue. Yeh et al. studied 10 different kinds of marine products, they found 
that total content of FA was $20 \mathrm{mg} / \mathrm{kg}$ more than free FA, the proportion of free content of FA ranged 39 percent among total FA [18]. Rehbein et al. found that free FA was $7.6 \mathrm{mg} / \mathrm{kg}$ while total FA was $38.5 \mathrm{mg} / \mathrm{kg}$ in Haddock, free FA was $6.5 \mathrm{mg} / \mathrm{kg}$ while total FA was $41.9 \mathrm{mg} / \mathrm{kg}$ in Pollack, free FA was $22.8 \mathrm{mg} / \mathrm{kg}$ while total FA was $114.5 \mathrm{mg} / \mathrm{kg}$ in cod [19]. The literature states that free FA is that which is of toxicological interest and that it should be measured. Low recovery is the disadvantage of detecting free FA, so the authors used a "recovery factor" [20].

In addition, FA in aqueous solution could form a hydrate with the formula $\mathrm{H}_{2} \mathrm{C}(\mathrm{OH})_{2}$ : the hydrate exists in equilibrium with various oligomers. FA further forms an insoluble white trimer and further polymerises to solid paraformaldehyde in aqueous solutions. Even unopened bottles of formalin sometimes had an insoluble white precipitate in the bottom. Any bottle of formalin standard solution which is not clear is unsuitable for use as a standard [10].

Table 1. The study of formaldehyde content in various organisms

\begin{tabular}{ccc}
\hline Food & FA content $[\mathrm{mg} / \mathrm{kg}]$ & Study \\
\hline Squid & $15.2 \sim 62.7$ & {$[9]$} \\
Bumbalo & $63.8 \sim 163$ & {$[10]$} \\
cod & $11 \sim 105$ & \\
Milk & 0.8 & {$[11]$} \\
meat & $2.9 \sim 20.7$ & \\
Plant material & $3.6 \sim 35.0$ & \\
\hline
\end{tabular}

\section{Detection Methods}

Detection methods of FA include spectrophotometry, chromatography, fluorescence method, colorimetry and electrochemical method. These determination methods have their own advantages and disadvantages, generally spectrophotometry and chromatography are used more. Table 2 . shows the comparation of different methods. Spectrophotometric method includes acetyl acetone method, phloroglucinol method, phenylhydrazine hydrochloride method, chromotropic acid method, magenta-sulphurous acid method, chromatography can be divided into gas chromatograph (GC) or gas chromatography mass spectrometer (GC-MS), high performance liquid chromatography (HPLC), ion chromatography (IC), thin-layer chromatography (TLC), etc.

Table 2.the comparation of different methods

\begin{tabular}{|c|c|c|c|c|c|c|c|c|c|}
\hline $\begin{array}{c}\text { stud } \\
\mathrm{y}\end{array}$ & method & $\begin{array}{c}\text { Forms of } \\
\text { FA }\end{array}$ & $\begin{array}{l}\text { Linearity } \\
\text { rage }\end{array}$ & LOD & LOQ & $\begin{array}{l}\text { Derivativ } \\
\text { e time }\end{array}$ & $\begin{array}{l}\text { Derivativ } \\
\text { e } \\
\text { temperat } \\
\text { ure } \\
\end{array}$ & Recovery \% & interference \\
\hline$[21]$ & \multirow{4}{*}{$\begin{array}{l}\text { spectrophot } \\
\text { ometry }\end{array}$} & Free & $0.8-23 \mathrm{ug} / \mathrm{ml}$ & $0.29 \mathrm{ug} / \mathrm{ml}$ & $0.88 \mathrm{ug} / \mathrm{ml}$ & $35 \mathrm{~min}$ & $\begin{array}{c}\text { Room } \\
\text { temperature }\end{array}$ & $96.2-100$ & $\begin{array}{l}\text { Only acetaldehyde } \\
\text { and hydrogen } \\
\text { interfere a little }\end{array}$ \\
\hline$[22]$ & & Free & $\begin{array}{c}0.0075-0.6 \mathrm{ug} / \\
\mathrm{ml}\end{array}$ & $0.0015 \mathrm{ug} / \mathrm{ml}$ & $0.0045 \mathrm{ug} / \mathrm{ml}$ & $15 \mathrm{~min}$ & $60^{\circ} \mathrm{C}$ & $98-107$ & $\begin{array}{c}\text { Only high } \\
\text { concentration of } \\
\text { hydrogen peroxide } \\
\text { interfere } \\
\end{array}$ \\
\hline$[23]$ & & Free & $0-20 \mathrm{ug} / \mathrm{ml}$ & $2 \mathrm{ug} / \mathrm{ml}$ & $6 \mathrm{ug} / \mathrm{ml}$ & $7.5 \mathrm{~s}$ & $100^{\circ} \mathrm{C}$ & $88.6-110.6$ & Little interference \\
\hline$[24]$ & & total & $0.01-0.1 \mathrm{ug} / \mathrm{ml}$ & $0.0029 \mathrm{ug} / \mathrm{ml}$ & $0.0087 \mathrm{ug} / \mathrm{ml}$ & $6 \min$ & $100^{\circ} \mathrm{C}$ & $98.3-101.1$ & $\begin{array}{l}\text { Little interferenceof } \\
\text { sugars and } \\
\text { acetaldehyde, } \\
\text { acetone }\end{array}$ \\
\hline$[25]$ & \multirow{4}{*}{$\begin{array}{l}\text { chromatogr } \\
\text { aphy }\end{array}$} & Free & - & $0.00892 \mathrm{ug} / \mathrm{ml}$ & $0.0268 \mathrm{ug} / \mathrm{ml}$ & distill & $100^{\circ} \mathrm{C}$ & $83-103$ & Little interference \\
\hline$[26]$ & & Free & $1-10 \mathrm{ug} / \mathrm{ml}$ & $0.319 \mathrm{ug} / \mathrm{ml}$ & $0.957 \mathrm{ug} / \mathrm{ml}$ & $30 \mathrm{~min}$ & $\begin{array}{c}\text { Room } \\
\text { temperature }\end{array}$ & $>95$ & Little interference \\
\hline$[10]$ & & Free & $25-200 \mathrm{mg} / \mathrm{kg}$ & $3 \mathrm{mg} / \mathrm{kg}$ & $10 \mathrm{mg} / \mathrm{kg}$ & $2 \min$ & $\begin{array}{c}\text { Room } \\
\text { temperature }\end{array}$ & 63 & Little interference \\
\hline$[11]$ & & total & $0.05-2 \mathrm{ug} / \mathrm{ml}$ & $0.5 \mathrm{ug} / 1$ & $5 \mathrm{ug} / 1$ & $15 \min$ & $100^{\circ} \mathrm{C}$ & $97.5-106$ & Little interference \\
\hline
\end{tabular}

Principle of spectrophotometry is to make FA react with a compound, and then detect the reaction product with a color under the specific wavelength; acetyl acetone method is the most common method in spectrophotometry. People constantly improve spectrophotometric method, through the combination of advanced technology, improve its accuracy, sensitivity, make it more convenient, fast, 
safe, and practical $[18,27]$. Nael et al. developed a method of detecting FA by using tryptamine TA in a sulfuric acid medium. Limit of quantitation (LOQ) was $0.88 \mu \mathrm{g} / \mathrm{mL}$. No interference was detected from commonly existing contaminates in the liquid samples e.g. phenol, antacids, sugars and related compounds [21]. Li et al. proposed a method based on the reaction of FA with methyl acetoacetate in the presence of ammonia. Maximum sampling throughput was about 21 samples/h with small interference [22]. Weng et al. demonstrated an on-chip microfluidic FA detection method. FA in eight different food samples of $2 \mu \mathrm{L}$ volume was determined within one minute [23]. Cui et al. developed a kinetic-spectrophotometric method for the determination of ultra trace amount of FA in food samples. The method was based on the oxidation of rhodamine $\mathrm{B}(\mathrm{RhB})$ by potassium bromate in sulfuric acid medium (FA as catalyst) [24]. Rozidaini used natural compound (onion juice), as a novel environmental-friendly chromogenic agent to detect the concentration of FA in aquatic products. This study demonstrates the potential application of onion juice as a simple, safe and environmental-friendly technique for determination of FA [28]. But this method was not discernible at concentration of FA exceeding $15 \mathrm{mg} / \mathrm{L}$.

Principle of chromatography is to analysis the reaction product of derivatization reagent and FA by GC or HPLC, which are extracted by organic solvent. Li et al. developed a HPLC method in order to investigate content of FA. Based on steam distillation and 2,4-dinitrophenylhydrazine (DNPH) derivatization, FA was analysis by HPLC using ODS-C18 column. [25]. Joseph described an improved derivatisation procedure. The formation of the DNPH FA derivative has been shortened to $2 \mathrm{~min}$ and a stabilizing buffer has been added to the derivative to increase its stability. The average recovery of free formaldehyde in spiked cod was 63\% [10]. The US FDA has set suggested recovery limits for residues of veterinary drugs in foods for quantitative methods for 10-100 ppm at 70-110\%. The author states that the recovery of a reactive residue such as FA, however, this guideline may not be applicable.

Bianchie valuated FA using a solid phase microextraction (SPME)-GC-MS method based on fiber derivatization with pentafluorobenzyl-hydroxyl-amine hydrochloride. LOD and LOQ were calculated respectively with values of 17 and $28 \mu \mathrm{g} / \mathrm{kg}$. This method had good efficiency recovery of $94.8 \%$ [29]. $\mathrm{Ma}$ et al. determined trace volatile $\mathrm{FA}$ in aquatic products by $\mathrm{aMoO}_{3} /$ polypyrrole intercalative sampling adsorbent with thermal desorption GC-MS. A good linear range was found in a concentration range from 0.02 to $20.35 \mu \mathrm{g} / \mathrm{L}$. The detection limit was achieved as $0.004 \mu \mathrm{g} / \mathrm{L}$ by this method. Good recoveries for spiked aquatic products were achieved in range of $75.0-108 \%$ with relative standard deviations of $1.2-9.0 \%$ [30].

Moreover, rapid detection methods are concerned by most scholars, such as using reference color card to detect FA in food [31]. The main advantages of the new analytical procedure are the low background level, high selectivity, and very little sample preparation for on-site analysis of FA in food for qualitative or semi-quantitative determination.

\section{Research Prospection}

Although there are various methods mentioned for the determination of FA, each detection method of FA cut both ways, spectrophotometry has some advantages of simple equipment, low cost and fast operation, and disadvantages of poor accuracy, worse sensitivity, and easily influenced by complex food matrix. Chromatography with high sensitivity, stable derivatives, strong resistance against interference, high recovery rate, convenient and rapid operation is widely used for detecting FA, however, it requires expensive apparatus, time-consuming, cumbersome process in extraction, which makes it hard to meet the market demand. Therefore, we should choose the most suitable test methods in daily detection activity. Meanwhile to provide a basis for law activities of the related governmental departments, more studies of background FA content in food should be added, as well as limited range of toxicology. 


\section{Acknowledgements}

This study was supported by the research grant (No.2015T08) supported by the East China Sea Fisheries Research Institute, Chinese Academy of Fishery Sciences.

\section{References}

[1] R.G. Liteplo, and M.E. Meek: Inhaled formaldehyde: exposure estimation, hazard characterization, and exposure-response analysis. Toxicol Environ Health Part B Vol. 6 (2003), p. $85-114$

[2] X.Q. Zhao and Z.Q. Zhang: Microwave-assisted on-line derivatization for sensitive flow injection fluorometric determination of formaldehyde in some foods. Talanta Vol. 80 (2009), p. 242-245

[3] IARC: Monographs on the evaluation of carcinogenic risks to humans. Lyon, France, International Agency for Research on Cancer Vol. 88 (2004) .

[4] F.X. Li, J. Lu, Y.J. Xu, Z.Q. Tong, C.L. Nie, and R.Q. He: Formaldehyde-mediated chronic damage may be related to sporadic neurodegeneration. Progress in Biochemistry and Biophysics Vol. 35 (2008), p. 393

[5] X.J. Tang and Y. Bai, Duong A: Formaldehyde in China: production, consumption, exposure levels, and health effects. Environment International Vol. 35 (2009), p. 1210-1224

[6] T. Noda, A. Takahashi, and N. Kondo: Repair pathways independent of the Fanconi anemia nuclear core complex play a predominant role in mitigating formaldehyde-induced DNA damage. Biochemical and Biophysical Research Communication Vol. 404 (2011), p. 206-210

[7] MINSAN-telegram no. 703/3266/6/1377 08.11.1985

[8] China's Ministry of Agriculture. Agricultural Industry Criteria, NY5172-2002.

[9] X. Zhang, X.S. Shen, D.M. Huang, C. Kong, Y. Wang, and Y.Q. Cai: Studies on the determination of formaldehyde in squid and bummalo. Advances in Engineering Research, Vol. 46 (2015), p. 20-22

[10] J.M. Storey, W.C. Andersen, A. Heise, S.B. Turnipseed, J. Lohne, T. Thomas and M. Madson: A rapid liquid chromatography determination of free formaldehyde in cod. Food Additives and Contaminants: Part A Vol. 32 (2015), p. 657-664

[11] L. Treezl, A. Csiba, S. Juhasz, M. Szentgyorgyi, G. Lombai and L. Hullan: Endogenous formaldehyde level of foods and its biological significance. Z Lebensm Unters Forsch A Vol. 205 (1997), p. 300-304

[12] W.J. Duan, D.Q. Zhou and R.L. Zhang: Investigation of Background Concentration of Formaldehyde in Fresh Fishery Products. Chinese Agricultural Science Bulletin Vol. 27 (2011), p. 383-390

[13] B. Soottawat, V. Wonnop and T. Munehiko: Partial purification and characterization of trimethylamine-N-oxide demethylase from lizardfish kidney, Comparative Biochemistry and Physiology Part B Biochemistry and Molecular Biology Vol. 135 (2003), p. 359-371

[14] J.R. Li and J.L. Zhu: Study on control of the formaldehyde-producing in the process techniques of Dosidicus gigas dried squid thread. Chinese Institute of Chemical Engineers Vol. 6 (2006), p. 200-203

[15] X.Y. Fu, C.H. Xue and B.C. Miao: Effect of processing steps on the physico-chemical properties of driedseasoned squid. Food Chemistry Vol. 103 (2007), p. 287-294

[16] C.H. Castell and B. Smith: Measurement of formaldehyde in fish muscle using TCA extraction and the Nash reagent. Fish Res Board Can Vol. 30 (1973), p. 91-98 
[17] H. Rehbein and T. Schmidt: A rapid and simple method for the determination of formaldehyde in fishery products. Fischwirtsch Vol. 43 (1996) p. 37-42.

[18] T.S. Yeh, T. Lin, C.C. Chen and H.M. Wen: Analysis of free and bound formaldehyde in squid and squid products by gas chromatography-mass spectrometry. Food and Drug Analysis Vol. 21 (2013) p. 190-197

[19] H. Rehbein, R. Schubring and W. Havemeister: Relation between TMAOase activity and content of formaldehyde in fillet minces and belly flap minces from gadoid fishes. Fishwirtsch Vol. 44 (1997), p. $114-118$

[20] I.E. Bechmann: Comparison of the formaldehyde content found in boiled and raw mince of frozen saithe using different analytical methods. Lebensm Wiss Technol Vol. 31 (1998), p. 449-453

[21] N.G. Yasri, H. Seddik and M.A. Mosallb: Spectrophotometric determination of formaldehyde based on the telomerization reaction of tryptamine. Arabian Journal of Chemistry Vol. 8 (2015), p. 487-494

[22] Q. Li, P. Sritharathikhum, M. Oshima and S. Motomizu: Development of novel detection reagent for simple and sensitive determination of trace amounts of formaldehyde and its application to flow injection spectrophotometric analysis. Analytica Chimica Acta Vol. 612 (2008), p. 165-172

[23] X. Weng, C.H. Chon, H. Jiang and D.Q. Li: Rapid detection of formaldehyde concentration in food on a polydimethylsiloxane (PDMS) microfluidic chip. Food Chemistry Vol. 114 (2009), p. 1079-1082

[24] X.J. Cui, G.Z. Fang, L.Q. Jiang and S. Wang: Kinetic spectrophotometric method for rapid determination of trace formaldehyde in foods. Analytica Chimica Acta Vol. 590 (2007), p. 253-259

[25] J.R. Li,J.L. Zhu, L.F. Ye: Determination of formaldehyde in squid by high performance liquid chromatography. Proceedings of the 4th Annual Conference of the east and west food top BBS of Chinese Institute of Food Science and Technology, Hangzhou, 11-13 November 2007, 127-130

[26] M.T. Oliva-Teles, P. Paiga, C. M. Delerue-Matos and M. C. M. Alvim-Ferraz: Determination of free formaldehyde in foundry resins as its 2,4-dinitrophenylhydrazone by liquid chromatography. Analytica Chimica Acta Vol. 467 (2002), p. 97-103

[27] Y. Zhu, Z. Peng, M. Wang, R.R. Wang, L.M. Rui: Optimization of extraction procedure for formaldehyde assay in smoked meat products. Food Composition and Analysis Vol. 28 (2012), p. 1-7

[28] M.G. Rozidaini and A.A. Wan: Development of formaldehyde detection method using onion juice as chromogenic agent. Desalination and Water Treatment Vol. 52 (2014), p. 1093-1100

[29] F. Bianchi, M. Careri, M. Musci and A. Mangia: Fish and food safety: Determination of formaldehyde in 12 fish species by SPME extraction and GC-MS analysis. Food Chemistry Vol. 100 (2007), p. 1049-1053

[30] Y.J. Ma, C.Zhao, Y.S. Zhan, J.B. Li,Z.M Zhang and G.K. Li: Separation and analysis of trace volatile formaldehyde in aquatic products by a MoO3/polypyrrole intercalative sampling adsorbent with thermal desorption gas chromatography and mass spectrometry. Separation Science Vol. 38 (2015), p. 1388-1393

[31] S. Wang, X.J. Cui and G.Z. Fang: Rapid determination of formaldehyde and sulfur dioxide in food products and Chinese herbals. Food Chemistry Vol. 103 (2007), p. 1487-1493 